https://helda.helsinki.fi

\title{
European constitutionalism
}

\section{Tuori, Kaarlo}

Cambridge University Press

2019

Tuori , K 2019 , European constitutionalism . in R Masterman \& R Schütze (eds), The Cambridge Companion to Comparative Constitutional Law . Cambridge University Press , Cambridge , pp. 521-553 . https://doi.org/10.1017/9781316716731.021

http://hdl.handle.net/10138/312573

https://doi.org/10.1017/9781316716731.021

unspecified

acceptedVersion

Downloaded from Helda, University of Helsinki institutional repository.

This is an electronic reprint of the original article.

This reprint may differ from the original in pagination and typographic detail.

Please cite the original version. 


\section{Kaarlo Tuori}

\section{European Constitutionalism}

1. Does the European Union possess a constitution?

1.1. Perspectivism of legal disciplines and legal orders

Much ink - too much, one could say - has been spilled in debating whether the EU possesses a constitution or not. This is not an issue where an objectively valid answer could be found. What is at stake is the basic legal vocabulary with which the EU is characterized. Alternative conceptual frameworks exist. More or less convincing arguments can be presented in favour of opting for each of these, but no second-order criteria exist for declaring any of them the winner of the argumentative game.

Alternative conceptual frameworks reflect, not only to the scholarly disagreements and individual efforts to stand out in scholarly debates, but also a more profound and interesting backdrop; namely, the perspectivism which labels law in general but which is especially accentuated in the context of the EU. We always approach the law from a particular perspective, and our perspective inevitably affects the legal cultural Vorverständnis (pre-understanding) through which our legal knowledge is filtered. Legal concepts form a central part of this Vorverständnis. Legal cultural perspectivism comes in three main guises: perspectivism of legal disciplines, legal orders and legal roles. Here we can focus on the perspectivism of legal disciplines and legal orders and skip that of legal roles, manifesting the different relations to law of, say, judges, scholars and legislators.

Different legal disciplines employ different legal concepts and offer different conceptualizations of "surface-level" legal phenomena; say, the Founding Treaties of the EU in. A constitutional lawyer may see in the Treaties a (formal) constitution - or, at least, a quasiconstitution; an administrative lawyer a delegation of administrative powers from the Member States to the EU; and an international lawyer an international treaty establishing an international organization. Such disciplinary perspectives are not wholly exclusive. In her account, a constitutional lawyer may find space even for administrative and international law aspects; an administrative lawyer for constitutional and international law viewpoints; and an international 
lawyer for constitutional and administrative law considerations. However, the main disciplinary perspective dictates the emphasis in the account and the legal vocabulary employed.

Yet, not only do disciplinary commitments affect our conceptual choices. Legal phenomena are always analysed in relation to a distinct legal order; a referential legal order, as we can call it. Especially when analysing legal phenomena which lie in the intersection of several legal orders - as does the EU - the conscious or unconscious choice of the referential legal order is of crucial importance. Obviously, the basic choice here is between the EU legal order and a Member State legal order. Evidently, conceptual frameworks which lead to negating or at least downplaying European-level constitutionalism, such as an administrative or international law approach, imply commitment to the latter, Member State perspective. Within the constitutional approach both the EU law and a Member State law perspective are possible. This has been made conspicuous by fundamental conflicts of authority between the ECJ and, say, the German Constitutional Court. Both courts employ a constitutional approach, but the ECJ examines the issue at stake from the perspective of EU constitutional law, while the German Court adopts the perspective of German constitutional law. Still, the perspectivism of legal order is not exhausted merely by the choice of the surface-level constitutional norms which are deemed applicable to the issue at hand. Legal orders do not consist merely of surface-level norms but include legal cultural layers, informing the Vorverständnis of legal actors. This also holds for constitutional law: constitutional culture, consisting of constitutional concepts, principles, theories and methods, possesses features specific to the respective legal order at issue.

In sum, when examining the debates on European constitutionalism we should be attentive to the perspectivism of both legal disciplines and legal orders. Commitment to a constitutional law approach does not necessarily imply acknowledgement of European constitutionalism. When the constitutional law approach is combined with the perspective of Member State law, rejection of the constitutional claim of European law is wholly conceivable, perhaps even probable. To speak of European constitutionalism requires a combination of constitutional law and European law perspectives. Such a combination defines the legal cultural starting-point of this Chapter.

Emphasizing the significance of legal cultural perspectivism does not imply immunizing scholarly arguments from criticism anchored in another perspective or negating the possibility of a wide divergence of views within each perspective. Thus, adopting the combination of constitutional law and European law perspectives does not exclude disagreements with other accounts sharing the same perspectival commitments. Indeed, because of the still emergent and 
contested nature of EU law culture, including EU constitutional culture, theoretical controversies are rather to be expected.

\subsection{The persistence of the state template}

Modern constitutionalism in both senses of the term, i.e. as specific constitutional practices and as the specific ideational basis of these practices, emerged in the context of modern states, to constitute, organize and delimit public power as state power. Constitutional concepts, starting from the very concept of constitution, bear traces if their origin. When transferred to the transnational level, to examine, say, the EU, we face the dilemma of translatability. On the one hand, concepts elaborated in the state setting offer the only available starting-point for transnational constitutional analysis. Furthermore, if national and transnational constitutionalism had nothing in common, it would be difficult to justify in the first place employing constitutional vocabulary at the transnational level. On the other hand, our conceptual framework should allow for the possibility that some typical features of national constitutionalism ${ }^{1}$ are wanting at the transnational level and that at this level constitutionalism displays aspects which do not find correspondence in the state setting. We should avoid thick concepts which may be warranted at the level of national constitutionalism but which tend to negate transnational constitutionalism or at least obscure the view to its particularities.

Scholars who reject transnational European constitutionalism or denigrate it to the status of quasi-constitutionalism employ a thick notion of constitutionalism, manifesting the state template. In the administrative law account of the EU, represented most prominently by Peter Lindseth, ${ }^{2}$ constitutionalism is located exclusively at the pole of Member States, while the relationship between Member States and the EU is explored through the (US) administrative law conceptual relationship of delegation and control between a principal and an agent. In this analysis, constitutionalism does play an important role but at issue is the polyarchic constitutionalism of the Member states; at the level of the EU, nothing worth the term of constitutionalism exists.

The administrative law account implies a thick normative notion of constitutionalism corresponding to the American understanding of a constitutional democracy and the European understanding of a democratic Rechtsstaat defined through the requirements of democracy and

\footnotetext{
${ }^{1}$ In this Chapter, 'national constitutionalism' and 'state constitutionalism' are used as synonyms.

${ }^{2}$ P. Lindseth (2010).
} 
fundamental rights. In this conceptual setting, 'constitutionalism' is intimately linked to legitimacy: 'constitutionalism' implies that the legitimacy of a polity and its law should be achieved through democratic procedures and fundamental rights. While Lindseth refuses to examine putative European constitutionalism in its interaction with national constitutionalism, he ends up by denying the justification for a constitutional depiction of the Union and its law. ${ }^{3}$

Dieter Grimm's writings ${ }^{4}$ offer another example of adoption of a state perspective - in Grimm's case, the perspective of German constitutional law; reliance on a thick definition of basic constitutional concepts; and a consequent scepticism of the constitutional credentials of the EU. Grimm defines modern constitution through five characteristics. 1. A constitution consists of legal norms and not of philosophic principles or a description of the actual power relationships in a polity. 2. Constitutional norms address the establishment and exercise of political rule (public power). It not only regulates and modifies public power but constitutes it. 3 . The constitution regulates political rule in a systematic, comprehensive manner, tolerating neither extraconstitutional powers nor extraconstitutional ways and means of rule. Historically, the emergence of a modern constitution was preceded by the emergence of the modern state; i.e. the concentration of the rights to rule into a state power as a uniform public power. 4. Political rule is only legitimate when constituted and limited by the constitution, and consequently constitutional law takes precedence over all other legal acts, which are valid only when they comply with the constitutional framework. 5. Constitutional norms must originate with the people, since every other principle for the legitimation of political rule would undermine the other elements of a modern constitution and prevail over the constitution in the event of a conflict.

Grimm emphasizes the significance for modern constitutionalism of the distinction between constituent and constituted power (pouvoir constituant and pouvoir constitué), made famous by abbé Siéyes: the constituent, constitution-making power lies with the people, while the bodies established by the constitution exercise constituted power. Closely related to the distinction between constituent and constituted power is another distinction; namely, that between procedures and principles of political decision-making and political decision-making itself. The procedures and principles of political decision-making fall under constituent power and belongs to the domain of the constitution, while political decision-making itself should be left to the

\footnotetext{
${ }^{3}$ D. Halberstam (2009, 2010 and 2102), another American observer of putative European constitutionalism, identifies constitutionalism with limited self-governance.

${ }^{4}$ Two volumes of Grimm's writings in constitutional law have recently appeared in English. D. Grimm (2016 and (2017).
} 
constituted power; i.e. to the bodies established by the constitution. Grimm does not explicitly mention democracy and fundamental rights - the main elements of a constitutional democracy or a democratic Rechtsstaat - as conceptual elements of a constitution but labels them achievements or standards of modern constitutionalism.

In Grimm's assessment, the Founding Treaties of the EU fall short of the criteria of a modern constitution mainly because of the lack a democratic pouvoir constituant as their source. The Treaties are treaties under international law which have been ratified in accordance with national constitutional requirements and which cannot be amended without the consent of the Member States. The Member States remain Masters of the Treaties. They may enjoy democratic legitimacy in individual Member States but they are not emanations of the sovereignty, i.e. the constituent power, of a European people. If the term 'constituent power' can in general be used in the European context, the constituent power falls to the Member States and not to the European people. Grimm concedes that a process of constitutionalization has occurred in the sense that in particular in the jurisprudence of the ECJ, the Treaties have been assigned constitutional functions and treated as "higher law". Grimm invokes the introduction of the direct effect of European law in van Gend en Loos and the principle of the supremacy of European law in Costa v Enel, as well as the extension of supremacy to cover even national constitutional law in Internationale Handelsgesellschaft. ${ }^{5}$ However, these developments have not transformed the Treaties into a constitution in the full sense of the term; at most, the Treaties deserve the denomination of a quasiconstitution. The minimum requirement for reaching the rank of a constitution would be the detachment of future Treaty amendments from the acceptance of the Member States; i.e. the abolishment of the Member States' position as Masters of the Treaties.

In Grimm's view, the EU's quasi-constitution also falls short of the achievements of modern constitutionalism, especially democracy. In line with many other observers, Grimm points to the legal, sociological and cultural obstacles to the development of the European parliament to a body representative of the European demos. However, he sees the main impediment to European level democracy in the violation of the crucial distinction between the conditions and the substance of political decision-making. The Treaties as a quasi-constitution do not regulate merely the procedure and principles of political decision-making but include substantive policy provisions in, for instance, competition law. The Treaties spill over to policy

\footnotetext{
${ }^{5}$ Case C-26/62 Van Gend en Loos [1963] ECR 3; Case C-6/64 Flaminio Costa v ENEL [1964] ECR 585; Case C-11/70 Internationale Handelsgesellschaft [1970] ECR 1125,
} 
issues which at the state level belong to the domain of ordinary laws and ordinary democratic decision-making. In this sense, constitutionalization of the Treaties has led to overconstitutionalization: to the narrowing of the field of political decision-making by the Council and the European Parliament, and the enhancement of the role of judicial decision-making by the Court and executive decision-making by the Commission. Constitutionalization has not been accompanied by a restriction of the substantive scope of the Treaties to issues of constitutional character.

Thick concepts of constitution and constitutionalism, such as those employed by Lindseth and Grimm, reflect the persistent dominance of the state template of constitutions and hence risk blocking the view to the specificity of European constitutionalism. This specificity comprises extension of constitutionalism to sectoral policy fields, its process-like, evolutionary nature and its constant interaction with national, Member State constitutionalism. The state template focuses on the juridical and political constitutions, and tends to neglect sectoral constitutions, a distinct feature of European constitutionalism which corresponds to the basic teleological, policy orientation of European law. Rather than seeing in sectoral constitutionalization an anomaly it should be treated as a particularity of European constitutionalism, distinguishing it from its state counterpart. In addition to the framing juridical and political constitutions, in the EU constitutionalization has covered policy fields, such as economy, social welfare and security.

Obsession with the concept of pouvoir constituant, labelling Grimm's contributions, leads easily to downplaying the process-like character of the European constitution and ignoring he centrality of evolutionary concepts for its examination. Finally, rejecting the existence of constitutionalism at the European level because of the putative failure to meet the legitimacy exigencies of a constitutional democracy intimates bypassing the constant interaction with Member State constitutionalism; i.e. the third distinctive feature of European constitutionalism.

In order to probe into the specificity of European constitutionalism, we should not burden our basic constitutional concepts with too demanding normative assumptions. 'Constitution' and 'constitutionalism' can and should also be used in a thinner, normatively more neutral sense, which detaches them from the state template and allow for examining the particularities which mark out European constitutionalism. Yet, of course, we must also keep in mind that in order to justify the use of constitutional vocabulary in the first place, European constitutionalism must be shown to display, not only divergences from, but also similarities to state constitutionalism. Similarities similarities include the position of constitution as higher law and the basic functions this higher law is expected to perform. 


\subsection{Constitution as higher law}

The idea of constitution as higher law can be given both a formal and a substantive reading. Ever since the Les Verts ruling in 1986, ${ }^{6}$ the ECJ has characterized the Founding Treaties as the constitutional charter of the EC (the EU), implying that these amount to a formal constitution. The ECJ's claim of the Treaties as a constitutional charter obviously involves the idea of higher or superior law. But superior to what law? One of the constitutional particularities of the EU is that superiority works in two directions: with regard to other EU law and with regard to the national law of the Member States. In the internal relations of EU law, the Treaties both enjoy primacy in norm conflicts and provide the competence basis for lower-level normative acts, such as regulations and directives. This corresponds to how Hans Kelsen, for instance, defined the superiority of the constitution in his hierarchical view of the legal order. ${ }^{7}$

With regard to Member State law, superiority is a more complicated issue and breaks with the clarity and unambiguity of Kelsen's conception. The superiority of EU law is reflected by the principle of supremacy of which the primacy of EU law over national Member State law in norm conflicts before national courts is a sub-principle. However, only directly effective Treaty norms enjoy primacy over conflicting national norms, but, to further complicate matters, so do other directly effective European norms, too, regardless of their position in the internal hierarchy of EU law. Moreover, the other characteristic of superiority which Kelsen attached to the hierarchical structure of law is wholly missing in relations between European and national law: EU law is not the basis of national law's validity. In sum, EU law and national law do not constitute a unitary hierarchical structure or Stufenbau as the application of Kelsen's ideas of constitutional superiority would require.

As regards a qualified amendment procedure as a formal criterion of the superiority of constitutional law, the Treaties clearly stand out from other EU law. The Treaty on the European Union sets out a particular drafting and decision-making procedure for Treaty revisions. Moreover, as amendments to international treaties revisions have to be ratified by every Member State in accordance with the national constitution. Those sceptical of the constitutional claims of the EU are prone to emphasize that the Treaties remain part of international law and the Member States Masters of the Treaties. According to the tenets of an either-or logic, the Treaties cannot

\footnotetext{
${ }^{6}$ Case C-294/83 Parti Ecologiste 'Les Verts' v Parliament [1986] ECR 1365.

${ }^{7}$ H, Kelsen (1989).
} 
possess both an international law and a constitutional character. Yet dichotomous thinking may be misleading. Why could the Treaties not both obey international law in their amendment procedures and function as constitutional law with respect to other EU law and Member State national law? Kelsen, for one, did not see any difficulty in an international treaty functioning as the constitution of a legal order. ${ }^{8}$

What further complicates labelling the Treaties as a formal constitution is the role of general principles in EU constitutional law. Some of the most pertinent constitutional principles are not enshrined in the Treaties but have been articulated in the case law of the ECJ; these include supremacy and direct effect, as well as efficacy (effet utile) and uniformity as meta-level justificatory principles. Initially, fundamental rights, too, were introduced into EU law as general principles through ECJ jurisprudence. The ECJ has expressly granted general principles constitutional status. ${ }^{9}$ Thus, even if the Treaties as a constitutional charter were characterized as a formal constitution, it is crucial to remember that not all constitutional norms are enshrined in explicit Treaty provisions.

The ECJ is a hybrid court with many functions, reflecting the hybrid character of the EU legal system and polity. ${ }^{10}$ It is not a mere constitutional court, but among its many tasks it does exercise functions which equal those of state constitutional courts: through judicial review, it guards the EU constitution as a higher law with regard to both lower-level EU law and national Member State law; it engages in protection of fundamental rights; it resolves conflicts of competence between the EU and the Member States in a way reminiscent of the role of a constitutional court in a federal state; and it settles disputes among the main EU institutions, such as the European Parliament, the Council and the Commission. Indeed, these functions of the ECJ are a major argument for applying constitutional concepts to the European level.

A typical vagueness can be observed in the formal contours of the EU constitution, brought about by the central role of the ECJ. A similar ambiguity affects the substance of this constitution in all its diverse dimensions; i.e. the substantive reading of the European constitution as higher law. The premise, however, should be clear enough: time and again, we are dealing with a loi fondamentale, a law of the basics, whether the juridical, political, economic, social or security constitution is at issue. These basics can be identified only through reconstructing the cultural or theoretical layers underlying "surface-level” Treaty law and doctrine. Yet, in its "subsurface" movement, too, European constitutionalism differs from typical state constitutionalism.

\footnotetext{
${ }^{8}$ H. Kelsen (1920), p. 194. See also the discussion in R. Schütze (2009), pp. 37-9.

${ }^{9}$ Case C-101/08 Audiolux and Others v Groupe Bruxelles Lambert and Others [2009] ECR I-9823, Para. 63.

${ }^{10}$ R. Dehousse (1998) analyses the ECJ as an international, constitutional and administrative court.
} 
In the state setting, legal cultural principles, which also produce the substantive coherence of the legal order, are typically closer to Ronald Dworkin's morally laden principles principles in sensu stricto - than policies related to goals and programmes concerning the desired state of society. ${ }^{11}$ What has detached European law from an ideal typical state legal order is its fundamental policy orientation which has left its impact on constitutional law, too. The policy orientation is most conspicuous in sectoral constitutions, but it has affected juridical constitutionalization as well. Such key principles of the juridical constitution as direct effect and supremacy were also motivated by policy considerations; by the effective and uniform application of European law which aimed at the establishment and functioning of the common market.

Accordingly, the substantive coherence which European law has achieved has been a result of policies rather than principles. However, building up sub-surface, legal-cultural foundations for policy-oriented law, including constitutional law, has been an arduous process. Within sectoral constitutions, Member State constitutional traditions can offer but meagre support for the development of EU constitutional culture. In central fields, EU law, comprising constitutional law too, has started cultural sedimentation from scratch: no national free movement law exists, and even national competition law is a relative newcomer.

In their sub-surface foundations, the juridical and political dimensions partly differ from the general picture. General policy orientation affects the European framing constitutions, too, as is shown by the backdrop to direct effect and supremacy, and the justificatory principles of efficacy and uniformity. Yet an important sub-field of the juridical and political constitutions exists which EU constitutional law shares with its national counterparts, where national constitutional traditions have been an important source and where morally laden principles temper the policy emphasis; namely, fundamental rights law. Maastricht enshrined in Treaty law the contribution of national constitutional traditions to fundamental rights as general principles of European law. ${ }^{12}$ In respect of fundamental rights law, it is also evident that EU and national legal systems share the same "deep culture" where the universalist values now listed in Art. 2 TEU find their place. ${ }^{13}$

\footnotetext{
${ }^{11}$ R. Dworkin (1978).

${ }^{12}$ Present Art. 6(3) TEU provides that "fundamental rights, as guaranteed by the European Convention for the Protection of Human Rights and Fundamental Freedoms and as they result from the constitutional traditions common to the Member States, shall constitute general principles of the Union's law". In the Preamble to the TEU, the Member States confirm "their attachment to the principles of liberty, democracy and respect for human rights and fundamental freedoms and of the rule of law".

13 "The Union is founded on the values of respect for human dignity, freedom, democracy, equality, the rule of law and respect for human rights, including the rights of persons belonging to minorities. These values are common to the Member States in a society in which pluralism, non-discrimination, tolerance, justice, solidarity and equality between women and men prevail."
} 


\subsection{Constitutional functions}

The functions the European constitution is expected to accomplish should be examined in a differentiated manner, attending to the specific features of distinct constitutional dimensions. The functions of the sectoral constitutions are not necessarily identical to those of the framing political and juridical constitutions. Constitutional functions must primarily be examined in the relationship of constitutional law and its object of regulation; i.e. the juridical and political subsystems for the framing constitutions and specific policy fields for the sectoral ones. However, as even the term 'framing constitution' intimates, the juridical and political constitutions accomplish important functions with regard to, not only their specific constitutional objects, but also the other, i.e. sectoral, constitutional dimensions. Thus, they provide the necessary legal and institutional means without which sectoral constitutionalization would not be possible. In particular through their fundamental rights part, they also play a restrictive role with regard to the sectoral ones.

The functions constitutions are expected to fulfil at both the national and transnational level can be discussed in the following framework:

- a constitutive function: bringing about the constitutional object;

- a positioning function: defining the position of the constitutional object in relation to other entities of the same kind;

- an organizing function: bringing order and stability into the constitutional object;

- a restrictive function: preventing the constitutional object from exceeding its limits;

- a legitimizing function: promoting the acceptance of the constitutional object among relevant addressees.

In the EU, the above functions can be discerned in both framing and sectoral constitutions. In the following, examples will be taken from the European political constitution. Analogously to typical state constitutions, it has fulfilled a constitutive function in respect of European polity. The institutional part of the political constitution defines the main institutions of the EU, as well as their competences and mutual relationships. The constitution is also supposed to render the 
institutional organization the order and stability necessary for its effective and frictionless operating. In a polity aspiring to meet the criteria of a democratic Rechtsstaat, the constitutive and organizing functions are accompanied by a restrictive one. Through fundamental rights, the constitution restricts the power that the institutions of the polity are allowed to wield with regard to individuals. Fundamental rights are not the only constitutional limitation on the powers of EU institutions. As a transnational, policy-oriented polity and differing from states, the EU does not possess a universal scope of activity, but its competences are limited to the substantive fields defined in the Treaties. The principle of conferral is an essential restrictive principle of the EU political constitution, distinguishing it from its Member States where the principle of comprehensive powers reflects the universality of a sovereign state's claim to political authority.

A political constitution defines the individual pole of the polity as citizens, endowed with citizenship rights, among which fundamental rights possess a privileged position. From the perspective of individuals, fundamental rights protect them against abuse of power by the institutional pole of the polity and guarantee them spheres of private and public autonomy. The exercise by citizens of their public autonomy renders a polity its democratic character.

In a nascent polity, such as the European one, the constitutive function should be examined in even broader, foundational terms. The political constitution is expected to contribute to the emergence of the polity itself, i.e. to accomplish a polity building function. For polity building, establishing and stabilizing the institutional organization and relating it to the individual pole of citizens does not suffice. Individual citizens should be interlinked as a citizenry; a demos capable of engendering the communicative power without which democracy would remain an empty promise of the formal constitution. Here the constitutional practices where European citizens jointly, across national borders, exercise their political autonomy are of crucial importance; it is only through these practices that European belongingness and solidarity or a European civil society and public sphere can develop. In polity building, the emergence of a constitutional culture shared by European legal or political elites does not suffice. What is needed is a civic constitutional culture forging individual citizens into a European citizenry; a source of communicative power controlling European political institutions and infusing them with democratic input legitimacy. As is well-known from the intensive debate of the EU's democratic deficit, the European polity-building process is only taking its first steps.

The constitutive function, so important for the political constitution of an emergent European polity, is accompanied by an equally important positioning function: defining the relations of the polity to other polities. This is a function of state constitutions, too, but it is particularly pertinent in a transnational polity, such as the EU. The basic positioning relates to the 
claim to autonomy that a constitution typically involves. Discussing the relevance of the claim to autonomy takes us back to the overall characterization of the EU and its law. Opting for the language of transnational constitutionalism entails attaching to the European constitution a claim to autonomy as well. Through this claim, the European political constitution distinguishes the EU polity from Member States and international organizations under public international law.

The organizational and restrictive functions are inseparable from the legitimizing one. For individuals, the political constitution of a democratic Rechtsstaat promises autonomy, citizenship and democracy. These promises are linked to the claim to legitimacy, so intimately associated with constitutionalism in its thick normative sense. The legitimizing function takes us to the constant interaction which EU constitutionalism maintains with national Member State constitutionalism; i.e. one of the distinctive features of EU constitutionalism. This interaction will be discussed in the last section of this Chapter.

\section{Multidimensionality of the European constitution}

As the "constitutional charter" of the EU, the Founding Treaties are bewildering reading for someone approaching them through the state template. Indeed, the general embarrassment among the citizenry confronted with the substance of the abortive Constitutional Treaty in the mid-2000s has been identified as one of the reasons for its rejection in the French and Dutch referenda. The Treaties contain an abundance of provisions which do not pertain to typical materia constitutionis of state constitutions; most conspicuously provisions on diverse policy fields. The European constitution is not only about European law and polity; it is also about European economy, European social welfare and European security. For scholars adopting the perspective and standards of state constitutionalism, such as Dieter Grimm, policy-related provisions blur the boundary which distinguishes principles and procedures of politics from its substance and which also should delimit constitutional from ordinary law. Such provisions are seen as an anomaly which attests to the quasi-nature of the European constitution and which should be removed.

State constitutions usually limit themselves to regulating the political and legal subsystems of society. The political and juridical dimensions exist in the European constitution as well. In the political dimension, constitutional law regulates the EU as a polity and in the juridical dimension the EU legal system. But EU constitutional law also constitutionalizes sectoral fields which at state level are usually the province of ordinary policy- and law-making. In state constitutions, the basic premise is the universality of the political and legal claim to authority within state territory; the principle of comprehensive powers, as we can also put it. State 
constitutions follow a territorial principle of authority, and, consequently, no sector-specific constitutional authorizations are needed. By contrast, the European Union does not adhere to a territorial but to a functional or substantive principle of authority. In accordance with the basic policy orientation of the EU, its juridical and political claim to authority is substantially (functionally) limited. Neither is the assumption of comprehensive powers valid for the European transnational polity and legal system; the principle of conferral substitutes for that of comprehensive powers. Not only must the European constitution provide the general juridical and political framework for sectoral policies; it must also set sectoral objectives and create sectoral competences. Consequently. the framing political and juridical constitutions are complemented by sectoral constitutions, such as economic, social and security constitutions. Furthermore, economic constitutionalization has produced a differentiation of two subfields: a microeconomic constitution, based on the Treaty of Rome but in important respects elaborated by the ECJ, and a macroeconomic one, based on the Maastricht provisions on Economic and Monetary Union (EMU). The microeconomic constitution is centred around free movement and competition law, and focuses on the economic activity of individual economic actors. In turn, the macroeconomic constitution addresses macroeconomic objectives and policies.

The sectoral constitutions possess distinct constitutional objects: European economy, social welfare and security. A corresponding differentiation is noticeable in Treaty law, as well as constitutional doctrine and theory. The exact contours of the sectoral constitutions can, though, be debatable. Should education be included in the constitutional object of the social constitution? Does the constitutional object of the security constitution cover both internal and external security? It might also be asked whether the sectoral constitutions should include, say, an environmental dimension. The decisive criterion consists of differentiation: arguably, neither primary environmental law nor the accompanying constitutional doctrine and theory have reached the required level of differentiation.

The term 'juridical constitution' may cause some confusion. All the constitutional dimensions possess a legal character in the sense that constitutional law always occupies one of the two poles of the constitutional relation; all the constitutional dimensions are about the constitutional relation between constitutional law and its constitutional object. What distinguishes the juridical constitution is the fact that here both poles of the constitutional relation are legal in nature. In the juridical constitution, the law establishes a reflexive relation to itself.

Thus, distinct dimensions can be discerned in the European constitution. Yet, their distinctness is not absolute but they enter into specific relations with each other. The very term 'framing constitutions' implies such inter-relationality. How, exactly, do the political and 
juridical constitutions frame the sectoral ones? Put briefly, the political constitution provides the institutional framework for sectoral constitutionalization, while the juridical constitution offers the legal instruments. The political constitution regulates the EU institutions to which sectoral competences are granted: such as the European Council, the European Parliament, the Council of Ministers, the Commission and the ECJ. At the individual pole of the polity relationship, the political constitution establishes and defines European citizenship, with potential implications in all sectoral dimensions. Correspondingly, sectoral constitutional dimensions rely on the legislative and judicial instruments, institutions and procedures provided by the juridical constitution. Moreover, the general principles developed in the course of juridical constitutionalization, such as direct effect, supremacy, the rule of law and fundamental rights, are pertinent in all sectoral dimensions. The framing constitutions exercise both a constitutive and a restrictive function with regard to the sectoral constitutions.

All the sectoral constitutions possess distinct political and juridical features as well: they have their characteristic institutional structures and legal particularities. The economic constitution cannot be examined without including the role of the Commission as the European Competition Authority or - after Maastricht - the ECB as the executor of European monetary policy. Correspondingly, in addition to general EU legal instruments sectoral constitutions have resorted to particular means, too, such as the Maastricht Social policy Protocol and Agreement in the social dimension or framework decisions in the security constitution. Institutional or juridical particularities should be discussed in the context of sectoral constitutionalization. But they should also be conceived of as elements in the overall European political and juridical constitutions. The political and juridical constitutions do not merely facilitate sectoral constitutionalization. They also react to and summarize its implications and consequences. In this sense the political and juridical constitutions are not only framing but also summarizing constitutions.

In a way, the EU reverses the relationship between the political and juridical constitutions and the sectoral policy fields to which we are accustomed at the state level. A state constitution is usually equated with the political and juridical dimensions which, according to the traditional understanding, establish the political and legislative sovereignty of the state. In turn, sectoral policies result from the exercise of this sovereignty. The political and juridical constitutions are primary in relation to sectoral policy fields which, as a rule, do not enjoy constitutional dignity. In a policy-oriented transnational polity and legal system, such as the EU, the claim to authority is substantively (functionally) limited. Juridical and political constitutionalization are not ends in themselves but largely respond to the needs and implications of sectoral constitutionalization. Economic constitutionalization would not have been possible without simultaneous juridical 
constitutionalization, which for instance produced the crucial principles of direct effect and primacy. Sectoral constitutionalization displays both formal and substantive aspects; by and large, the formal aspect of sectoral constitutionalization coincides with juridical constitutionalization. In turn, the Maastricht Treaty, which for instance reinforced the position of the European Parliament and introduced European citizenship, signified a leap in political constitutionalization. An important backdrop to this leap consisted of the legitimacy deficit which was perceived to have ensued from the preceding economic constitutionalization driven by the ECJ. In the European constitution, too, the framing political and juridical dimensions enjoy constitutive primacy. But they are subjected to the functional primacy of sectoral constitutions. The relationship between framing and sectoral constitutions is recursive: through their functional primacy sectoral constitutions trigger juridical and political constitutionalization, the results of which will then be available for subsequent framing purposes.

European integration has primarily been an economic project, and in spite of the expansion of EU activities into new policy domains, economic integration still retains a dominant position. This has left its imprint on inter-dimensional relations within the European constitution. The economic constitution has benefited from a functional primacy with regard not only to the framing constitutions but other sectoral constitutions as well. The functional primacy of the economic constitution can be observed not only in juridical constitutionalization but in the emergence and further development of non-economic sectoral constitutions, too. The social policy provisions of the Treaty of Rome had an economic rationale: they served free movement of workers or securing a level playing field for the industries of different Member States. In turn, the origins of the security dimension lie in the consequences of opening internal Community borders in order to implement free movement of workers, which is an essential element of the economic constitution. The functional primacy of the economic constitution has also limited the developmental options of the non-economic constitutions, as can be seen in the subjection of healthcare and social security to free movement and competition law.

Still, the functional primacy of the European economic constitution should not be understood in absolute terms. Although owing their initial momentum to the economic constitution, in their further development non-economic constitutional dimensions may have obtained at least partial independence from economic considerations. The original institutional organization of the Community - the nascent institutional pole of the European polity - was largely tailored to the needs of the economic constitution, but subsequently, say in and since Maastricht, specific political values, such as democracy and transparency, have gained in importance in political constitutionalization. In the security dimension, the scope of the risks to which the security 
constitution responds has expanded and transcends those deriving from the opening of internal borders. Similar signs of independence - or at least striving for independence - are detectable in the social constitution, too. A model example of growing autonomy is offered by the way the Treaty provision on equal pay was progressively detached from its economic rationale and turned into a nucleus of EU antidiscrimination law. The gradual development of constitutional social rights also reflects an aspiration for independence, although cross-border social rights in particular owe much of their initial dynamics to the implications of the economic constitution. Free movement of workers has provided the impetus to the right to cross-border social security and free movement of services to the right to cross-border healthcare.

The at least partial independence of the social constitution points to yet another type of relations between constitutional dimensions: relations of conflict. Increasing autonomy may lead to normative results which contradict the requirements of the economic constitution. The normative implications of the economic constitution may clash with those of, say, the political or social one. Before the ECJ, such constitutional conflicts often assume the guise of a contestation between different types of rights. Economic rights derived from free movement law may clash with social rights, or civil or political fundamental rights. In a standard constellation before the ECJ, the issue is whether protection of other types of rights justifies derogating from economic rights; reference can be made to such celebrated rulings of the ECJ as Omega, Schmidberger, Viking and Laval. ${ }^{14}$ The functional primacy of the economic constitution is obvious in the very posing of the issue: in conflicts of rights, what needs justification is restricting not a fundamental right but an economic right. Yet, as Omega and Schmidberger demonstrate, functional primacy does not necessarily dictate the result of the balancing exercise.

Economic rights possess an instrumental character; they serve the basic policy objective of establishing and securing the functioning of the common (internal) market. The conflictual relations between the economic and the political or social constitutions can often be conceptualized as a tension between policy-oriented economic rights and principle-based fundamental rights. The above-mentioned landmark cases also point to an aspect of conflict resolution in the framing function of the juridical constitution. The juridical constitution may be called upon to resolve inter-dimensional constitutional conflicts.

\footnotetext{
${ }^{14}$ Case C-36/02 Omega Spielhallen [2004] ECR I-9609; Case C-112/00 Schmidberger [2003] ECR I-5659; Case C438/05 International Transport Workers' Federation and Finnish Seamen's Union [2007] ECR I-10779; Case C-341/05 Laval un Partneri [2007] ECR I-11767.
} 
Constitutionalism is not only about surface-level constitutional law, enshrined in constitutional provisions and precedents. It is also about the constitutional culture animating constitutional practices, informing the Vorverständnis of constitutional actors and acting as a filter through which surface-level constitutional material is approached. As the Treaties constitutionalize sectoral policy areas and objectives, they also constitutionalize disagreements on the background assumptions of sectoral policies. In sectoral constitutionalization, European constitutionalism has not been able to draw on Member State constitutional traditions, and the contestedness of the theoretical underpinnings has delayed development of a distinct constitutional culture, impregnating the Vorverständnis of European constitutional actors.

In accordance with the basic teleological nature of the EU, the constitutional theories which in the diverse sectoral dimensions have created coherence in EU constitution have been policy-oriented. However, policy issues are controversial issues, and the constitutional theories underlying constitutional law have been subject to contestation, too. Examination of sectoral constitutionalization shows how controversial are constitutional theories in the various dimensions. Within the microeconomic constitution, the main frontline separates advocates of market liberalization from those who accept the possibility and need of national or European public regulation; within the macroeconomic constitution Monetarists have been confident of EMU becoming an optimal currency area while Economists have stressed the necessity of common economic policies as a precondition for common monetary policy; within the social constitution the primacy of national welfare regimes collides with the prevalence of the economic constitution, and national solidaristic justice confronts European access justice; and, finally, within the security constitution, security and fundamental rights considerations clash with each other, as does transnationalism with state-sovereigntism and intergovernmentalism.

\section{The evolutionary nature of the European constitution}

State constitutions are usually examined as unitary normative entities, the tacit assumption being that juridical and political constitutions emerge and develop parallel to each other. By contrast, the multidimensional European constitution has resulted from a differentiated process, displaying diverse temporalities. The European constitutional dimensions have not appeared simultaneously but, rather, successively. Nor have they followed exactly the same developmental path. Typical of European constitutionalism is - to borrow Ernst Bloch's expression - Gleichzeitigkeit des Ungleichzeitigen. 
The upsurge of theoretical interest in European constitutionalism has involved efforts to apply to the European context the tripartite conceptual cluster of constituent power (pouvoir constituant), demos as the subject of this power and constitutional moment as the instance when this power is wielded. These efforts have not been particularly successful. The elevation of 'constituent power' to a central constitutional concept has led Dieter Grimm to denigrate the Treaties to a quasi-constitution. Conceptual dilution is an alternative consequence of clinging to concepts coined in a specific branch of constitutional culture: revolutionary American and French constitutionalism. We have drifted far from the original conceptual connotations if we define the Member States as Masters of the Treaties (Herren der Verträge) as a European demos or their treaty making power as a pouvoir constituant the exercise of which has produced the European constitution. The concepts of revolutionary constitutionalism are not applicable to the European constitution, which has not resulted from the exercise of constituent power by a European demos at an identifiable constitutional moment.

Instead of a revolutionary break, the many constitutions of Europe are a continuously evolving outcome of an ongoing process. This process does include such high-profile occasions as agreements on new Treaties and Treaty amendments, but to label these as constitutional moments is rather farfetched. Furthermore, they do not exhaust the process of constitutionalization. Even more fanciful would be employ concepts of the revolutionary constitutional tradition in the context of landmark decisions by the ECJ, such as van Gen den Loos and Costa v Enel; decisions which were crucial for juridical constitutionalization but whose constitutional significance was, outside of a narrow circle of initiates, realized only long afterwards. Instead of the cluster of revolutionary-tuned concepts of constituent power, demos and constitutional moment, the European constitution(s) should be examined through the evolutionary concept of constitutionalization, as a multidimensional and multitemporal process of constitutionalization. In the European context, 'constitutionalization' simply refers to the gradual, incremental development of the European constitution in its various dimensions and by various constitutional actors; not only by the Member States as a constitutional legislator but also the ECJ as a constitutional court, assisted by European law scholars.

Distinct periods can be discerned in European constitutionalization. These receive their particular colouring from a particular constitution; a pacemaker constitution, as it were. Reflecting the temporal and functional primacy of economic integration, the first wave, initiated by the Treaty of Rome, or even earlier by the Treaty of Paris (1951) establishing the European Coal and Steel Community (ECSC), proceeded under the auspices of the economic constitution. The rulings of the ECJ defining the basic principles characterizing Community law as an independent legal system manifested the significance of the juridical constitution: juridical and economic constitutionalization 
proceeded in tandem. The Maastricht Treaty epitomized the at least temporary dominance of the political constitution. In turn, the Amsterdam Treaty (1998), with its new provisions on the Area of Freedom, Security and Justice, inaugurated the prominence of the security constitution, which was further reinforced by European reactions to 9/11. Subsequently, the Eurozone crisis catapulted the economic constitution back to the pacemaker role. However, if the emphasis in the Rome Treaty and the succeeding case law of the ECJ lay on the microeconomic constitution, the crisis highlighted the role of the macroeconomic layer. The pacemaker role of the macroeconomic constitution entailed that the constitutional mutation launched by the Eurozone crisis was not restricted to the economic aspect. It extended to the political and social dimensions as well; it also affected democracy and transparency, as well as social values and rights. Finally, the immigration crisis which broke out in 2015 and the vote for Brexit in June 2016 shifted the emphasis to, respectively, the security and the political dimension.

Related to 'constitutionalization', other process-oriented concepts are of particular relevance for European constitutional analysis. These include 'transnationalization' and 'individualization'. In important respects, constitutionalization has signified transnationalization: superseding intergovernmental institutional and decision-making structures, typical of international organizations, as well as detaching European law from the international law background. However, when examining European constitutionalization 'transnational' and 'intergovernmental' should not be straightforwardly opposed. In the institutional organization of the EU, the Commission, the ECJ and the European Parliament make up the transnational core. But even the European Council and the Council of Ministers are institutions of a transnational polity, and the transnational setting leaves its imprint on institutions with an intergovernmental composition, too. In turn, the Treaties still possess the dual character of "a constitutional charter" and an agreement under international law. Moreover, in both the social and security dimensions, international law agreements have played an important role as precursors to constitutionalization through Treaty provisions. In combating the Eurozone crisis, Member States resorted to agreements under international law as an alternative to primary or secondary Union law. The third-Pillar Treaty provisions in force from 1993 to 2009 even explicitly constitutionalized international law conventions as an EU legal instrument.

Constitutionalization has implied individualization: establishment of direct links between European institutions and European citizens in their diverse attires. From the perspective of European individuals, the multidimensional process of constitutionalization has involved a gradual enrichment of European citizenship, adding successive layers to the initial market citizenship of the economic constitution: the judicial citizenship of the juridical constitution; the social citizenship of the social constitution; and finally the political citizenship which grants individuals not only the specific 
citizenship rights of the Treaty but European fundamental rights as well. Still, European citizens also remain citizens of Member States, and the relations between European institutions and individual citizens hint at the relevance of the Member State level, too.

In sum, 'constitutionalization' is an evolutionary alternative to the revolutionary concepts of pouvoir constituant, demos and constitutional moment. Particular relations exist among the constitutional dimensions, such as the functional - and temporal - primacy of the economic constitution and the general functional primacy of sectoral constitutionalization in respect of the framing juridical and political constitutionalization. Such relations hint at a particular internal logic guiding European constitutionalization. Still, it is important to stress that European constitutionalization should not be reconstructed as a closed, linear and pre-determined evolutionary process. Different constitutions may well clash with each other, and constitutional backlashes form part of the picture as well. And even more crucially, we should always bear in mind that the ultimate factors accelerating or impeding constitutionalization are of an extra-legal and extra-constitutional, economic, political and ideological, nature. These factors may include high-profile, even crisis-like events, such as the fall of the Berlin wall and the reunification of Germany (the Maastricht Treaty as a high-point of political constitutionalization); 9/11 (acceleration of the development of the security constitution); the global financial crisis which in the autumn of 2008 broke out following the collapse of Lehman Brothers (the teetering of the Maastricht principles of the European economic constitution); the eruption of the migration crisis in the winter 2015-2016 or the Brexit referendum in 2016. Still, equally well constitutionalization may be influenced by contingent events which on their occurrence have aroused no public attention but which have, for instance, produced constitutionally relevant case law of the ECJ.

\section{Transnational and national constitutionalism}

4.1. Constitutional pluralism and federal constitutionalism

During the last twenty years, constitutional pluralism has largely dominated scholarly discussion on the relations between the European constitution and its national counterparts. The debate does address an important aspect in the relations that the European transnational constitution entertains with Member State national constitutions: the overlapping and rival claims of authority that these constitutions raise. Indeed, the very concept of legal or constitutional pluralism can be defined as a constellation where two legal regimes raise such overlapping and conflicting claims of authority. Pluralist constellations are typical of our age of postnational law. Conflicts of authority seem to be inevitable between transnational law, such as EU law, and national law, such as Member State law. 
Transnational and national law follow different principles of authority; the scope of their authority is circumscribed through different criteria. National law adheres to the territorial principle of authority and claims universal jurisdiction in in its territory. By contrast, transnational law's claim of authority is substantially or functionally defined and limited. Territorial and functional principles of authority are bound to clash, producing at regular intervals fundamental conflicts of authority; that is, conflicts turning on the autonomy and identity of the colliding legal regimes. The celebrated cases involving the German Constitutional Court and the Luxembourg Court - the OMT case ${ }^{15}$ is the latest but will not remainthe last example - intimate how high the stakes are: the German Constitutional Court sees itself as the guardian of German constitutional identity and the autonomy of German law, while the ECJ defends the autonomy and constitutional identity of EU law. Such fundamental conflicts of authority are widely different from the border skirmishes that are addressed by private international law or, as the Anglo-American term goes, conflict of laws. However, the exchange of arguments between the German Constitutional Court and the Luxembourg Court in, for instance, the OMT case not only shows the inevitability of fundamental conflicts of authority under the pluralism of postnational law. It also testifies to the possibility of a dialogical resolution or, at least, pacification of these conflicts. The relationship between the function-specific EU constitution and universalist Member State constitutions is not labelled only by actual or latent conflicts. It is also marked by dialogue and co-operation, facilitated by a shared constitutional deep culture; in brief, by normative and institutional interlegality.

In addition to its conflictual focus, the debate on constitutional pluralism has been onesided in another respect, too. It has addressed the consequences of the overlap of national and transnational claims of authority merely in the juridical and political dimensions. However, Member States' defence of their political and legislative sovereignty - the universality of their political and legal claims to authority - has had implications for European sectoral constitutions, too. Member States have raised sovereignty concerns vis-à-vis EU action with regard to fiscal and other economic policy; welfare policy and the choice of welfare regimes; and use of the coercive power of the state, the state's "monopoly of legitimate use of violence".

In fundamental conflicts of authority, typical of the pluralist constellation, each party say, the ECJ and a national constitutional court - approaches the issue from the perspective of its referential legal order - say, EU law and the national legal order, respectively. Perspectivism of legal orders is inevitable. As constitutional pluralists have emphasized, no second-order legal principle or

\footnotetext{
${ }^{15}$ The contributions of the German Constitutional Court are Beschluss vom 06. Juli 2014 - 2 BvR 2728/13 and Urteil vom 21. Juni 2016 - 2 BvR 2728/13, and the ECJ interventions Opinion of Advocate General Cruz Villalón delivered on 14 January 2015, C-62/14 - Gauweiler and Others and C-62/14 - Gauweiler and Others.
} 
neutral arbiter exists to resolve the conflict. In this sense, the conflicts are undecidable. This observation has been picked up by theorists of federal constitutionalism, such as Robert Schütze, and related to notion of Staatenverbund or - in Schütze's translation - federal union. What is considered characteristic of a federal union is the very undecidability of fundamental conflicts of authority (sovereignty). If such conflicts were to be resolved in favour of the union, it would develop into a federal state; if, in turn, in favour of the states, the union would be degraded to the status of an international organization. ${ }^{16}$ In line with the debate on constitutional pluralism, federal constitutionalism points to an important aspect in the relationship of European and Member state constitutionalism. However, it also shares the one-sided conflictual focus and the reduction of the European constitution to its juridical and political dimensions.

\subsection{Relations of complementarity}

The conflict-oriented view of constitutional pluralism tends to obscure another, equally important aspect in the relationship between the transnational European constitution and the national Member State constitutions: complementarity. Treaty provisions on the respective competences of the Union and the Member States may be read to imply a division of labour, based on a relationship of complementarity. Yet this can be an erroneous reading. Complementarity in the sense of division of labour presupposes common objectives; only with regard to common objectives can an expedient division of labour and corresponding allocation of competences be adopted. But division of competences, such as it is enshrined in the Treaty on the European Union, does not necessarily imply a division of labour: division of competences may free the Union and Member States to pursue their distinct objectives and policies within their fields of competence. It is misleading to assume that the Union and its Member States constitute in every relevant respect a multilevel Verfassungsbund where relations between the transnational and the national are primarily characterized by intertwinement and complementarity. ${ }^{17}$ In the field of shared competences, the principle of subsidiarity, as formulated in Art. 5(3) TEU, does presuppose the existence of common objectives; the Union will step in only if the objective at issue cannot be better achieved by lower-level action. A presumption of common objectives, grounded in a common value basis whose existence Art. 2 TEU postulates, also facilitates an understanding of the demarcation between national and Union fundamental rights review in terms of complementarity.

\footnotetext{
${ }^{16}$ R. Schütze (2014).

${ }^{17}$ The idea of a multilevel Verfassungsverbund was propounded, first of all, by Ingolf Pernice. See, e.g., I. Pernice (2009).
} 
All the sectoral European constitutions imply relations of complementarity. Take the economic constitution. EU constitutional law does not comprise all the constitutional guarantees which must be in place to enable a European internal market, based on undistorted competition. The fundamental rights that a market economy requires are mainly ensured by national constitutions; by national constitutional provisions on the right to property, freedom of contract and freedom of trade. Hence, the European microeconomic constitution, covering primarily the fundamental market freedoms and competition law, is premised on the complementary contribution of Member State constitutions. In turn, the European macroeconomic constitution has presupposed, say, Member State financial and economic policy autonomy, although its use has been subjected to European constraints. In the social dimension, the European constitution has relied on the existence of national redistributive welfare regimes. Finally, in the security dimension, too, core security functions and their judicial supervision have been retained under Member State sovereignty and taken by the European security constitutions as a given premise.

The relation of complementarity is also conspicuous in the field of citizenship, which brings us to the dimension of the political constitution. European citizenship builds on national citizenship, and not only in the sense of the identification of individual citizens - by definition, Member State citizens are also EU citizens. Complementarity labels the participatory rights of European citizens as well. In their EU constitutional practices, in debating EU issues and in participating in the European public sphere, EU citizens rely on the public autonomy guaranteed to them as Member State citizens; the freedoms of assembly, association and the press enshrined in national constitutions. And if we in general can speak of European citizenship in collective terms, as European citizenry, this collective political subject can only exist as a result of the networking of national citizenries and national public spheres.

\subsection{Two-stage legitimation}

Opting for thin notions of constitution and constitutionalism does not imply denying the relevance for European constitutionalism of the normative ideas of a constitutional democracy (a democratic Rechtsstaat) or the conception of legitimacy it implies. However, efforts to secure democratic constitutional legitimacy should be examined through the interaction between transnational and national constitutionalism. As an epitome of transnational constitutionalism European constitutionalism has been, and still is, in some vital respects, parasitic on Member State national constitutionalism. This also holds for constitutional and democratic legitimacy, where the complementary relationship between national and transnational constitutionalism - alongside with its 
process-like and multi-dimensional character the third distinctive feature of European constitutionalism - is particularly important.

Paradoxically, perhaps, the Treaties owe their original constitutional legitimacy to their international law aspect, to the fact that they have been ratified by national parliaments or in referendums, in accordance with the provisions of the national constitution. However, the initial legitimacy which the EU may derive from Member States' acting as Masters of the Treaties does not suffice. The claim to legitimacy must be constantly re-redeemed. This concerns both system legitimacy - the overall legitimacy of the EU - and the policy legitimacy of individual policies and institutions responsible for these. Let us rely on Fritz Scharpf's distinction between democratic input legitimacy and result-based output legitimacy. ${ }^{18}$ In state constitutions, provisions on legislative and budgetary procedures, as well as participatory citizenship rights, aim to produce democratic input legitimacy at both system and policy level. In turn, provisions on independent expert bodies, such as courts or central banks, seek to facilitate output legitimacy in terms of, say, impartial and reasoned adjudication or monetary policy objectives, such as monetary stability.

At the European level, the distinction between system and policy legitimacy has not been very sharp. Especially in the early, pre-Maastricht decades, European integration as a whole could be understood as a cluster of specific policies ${ }^{19}$ and assessed in terms of output legitimacy. Bracketing the second-order objective of maintaining peace in Europe, what was decisive was whether the promise of increased economic prosperity (re)distributed through national mechanisms was kept or not. However, enlargement of European competences through ECJ case law and the prominent role of the ECJ in European law- and constitution-making in general raised concerns about the need for democratic input legitimacy. The boost to political constitutionalization in Maastricht responded to these concerns.

Reflecting the initial technocratic policy orientation of European integration, prominent in, for instance, Jean Monnet's functionalism, the Treaty of Rome largely ignored the issue of democratic legitimacy. The Member States ratified the Treaties according to their constitutional requirements, and the democratic legitimacy this produced was considered sufficient. However, embryos of democratic legitimation of European policy-making, too, were inserted even in the Treaty of Rome through the Council and the Assembly (European Parliament). These embryos manifested the twostage mechanism of democratic legitimacy which is such a distinct feature of European constitutionalism and the significance of which has grown in line with the widening of European

\footnotetext{
${ }^{18}$ F. Scharpf (1999), pp. 6-8.

${ }^{19}$ Such an understanding was implicit in Hans Peter Ipsen's often-cited characterization of the European Communities as Zweckverbände funktioneller Integration. H. P. Ipsen (1972).
} 
competences. The contribution of national democratic procedures to the legitimacy of European policies is a vital epitome of the complementary relation between national and European constitutionalism. Peter Lindseth's administrative law portrayal of the EU not only ignores sectoral constitutionalization. From its exclusive Member State perspective, it also refuses to examine European constitutionalism through interaction between the transnational and national levels, and declines to place national democratic procedures of control, oversight and implementation in the context of European constitutionalism.

In the course of political constitutionalization, efforts have been made to create direct legitimating relations between European citizenry and European institutions, most notably through direct election of the European Parliament and the introduction of European citizenship. However, as the low turnout in European elections has most dramatically proved, the cultural and social prerequisites for the formation of a European civil society and public sphere, capable of sustaining a Europe-wide democracy, are still largely lacking. On their own, European constitutional practices, culminating institutionally in the election of the European Parliament and its legislative and supervisory powers, can hardly live up to the high expectations of the thick normative concept of constitutionalism. This has only accentuated the importance of the contribution of national constitutionalism to the democratic legitimacy of the EU.

Intergovernmental EU institutions work under the guidance of national democratically legitimated bodies, and national parliaments even participate directly in Union law-making. Furthermore, the major part of Union legislative and other measures are implemented and enforced by national authorities. EU directives are transposed into the municipal legal order by the national legislator, thereby receiving an injection of democratic input legitimacy. Furthermore, nationally applicable EU law is integrated into the whole of the national legal order and, as it were, scrounges off the general legitimacy of the latter. In Jürgen Habermas's distinction between regulatory law (law as a medium) and law as an institution, ${ }^{20} \mathrm{EU}$ law has mainly fallen into the former category. Law as an institution is intimately related to the moral and value texture of society; hence, this department of law is vital to the overall substantive legitimacy of the legal order. Insofar as EU law enjoys substantive legitimacy, it is at least partly parasitic on the substantive legitimacy of national legal orders. In sum, the fact that the general public has primarily confronted EU measures, not directly, but indirectly, through the political and administrative institutions and the legal system of the

\footnotetext{
${ }^{20}$ J. Habermas (1989), p. 365.
} 
respective Member State, has been crucial for the legitimacy that the Union and its individual policies have enjoyed among European citizenry. ${ }^{21}$

As Lindseth has shown, Member State parliamentary oversight of European policies has intensified during recent decades. Yet, contrary to what Lindseth contends, this is not an argument for rejecting the existence of European constitutionalism. The interaction between the transnational and national levels belongs to the distinct of European constitutionalism. This interaction is vital for providing European institutions and policies with democratic legitimacy. Although this can hardly be seen as a decisive argument, it might still be worth mentioning that the Treaty of Lisbon explicitly recognizes the role of Member State constitutionalism in realizing the democratic principle. Art. 10 TEU proclaims that the functioning of the Union is founded on representative democracy. Not only are citizens directly represented at Union level in the European Parliament. In addition, Member States are represented in the European Council by their heads of state or government and in the Council by their governments. In turn, these representatives are themselves democratically accountable either to national parliaments or citizens. Art. 10 TEU expressly confirms the complementarity of direct European democracy and the two-level mechanism which harnesses national procedures to the service of European level democratic legitimacy. ${ }^{22}$

\footnotetext{
${ }^{21}$ F. Scharpf (2012), p. 19.

${ }^{22}$ On the specificity of European constitutionalism see also Tuori (2015).
} 


\section{Bibliography}

Dehousse, R., The European Court of Justice: The Politics of Judicial Integration (Basingstoke: Macmillan, 1998).

Dworkin, R., Taking Rights Seriously (London: Duckworth, 1978).

Grimm, D., Constitutionalism: Past, Present, and Future (Oxford University Press, 2016).

Grimm, D., The Constitution of European Democracy (Oxford University Press, 2017).

Habermas, J., The Theory of Communicative Action, Vol. 2 (Cambridge: Polity Press, 1989).

Halberstam, D., 'Constitutional heterarchy: The centrality of conflict in the European Union and the United States' in J. Dunoff and J. Trachtman (eds.), Ruling the World? Constitutionalism, International Law, and Global Governance (Cambridge University Press, 2009), 326-55.

Halberstam, D., 'Local, global and plural constitutionalism: Europe meets the world' in G. de Búrca and J. H. H. Weiler, The Worlds of European Constitutionalism (Cambridge University Press, 2010), 150-202.

Halberstam, D., 'Systems pluralism and institutional pluralism in constitutional law: National, supranational, and global governance', in M. Avbelj and J. Komárek (eds.), Constitutional Pluralism in the European Union and Beyond (Oxford: Hart, 2012), 85-125.

Ipsen, H. P., Europäisches Gemeinschaftsrecht (Tübingen: J. C. B. Mohr, 1972).

Kelsen, H., Allgemeine Staatslehre (Berlin: Springer, 1920).

Kelsen, H., Pure Theory of Law (Gloucester, Mass.: Peter Smith, 1989).

Lindseth, P., Power and Legitimacy: Reconciling Europe and the Nation-State (Oxford University Press, 2010).

Pernice, I., 'The Treaty of Lisbon: Multilevel constitutionalism in action', Columbia Journal of European Law, 15 (2009), 349-407.

Scharpf, F. W., Governing in Europe: Effective and Democratic? (Oxford University Press, 1999).

Scharpf, F. W., Legitimacy Intermediation in the Multilevel European Polity and its Collapse in the Euro Crisis (Cologne: Max Planck Institute for the Study of Societies, 2012).

Schütze, R., From Dual to Cooperative Federalism: The Changing Structure of European Law (Oxford University Press, 2009).

Schütze, R., Constitutionalism and the European Union, in C. Barnard and S. Peers (eds.), European Union Law (Oxford University Press, 2014), 71-96.

Tuori, Kaarlo: European Constitutionalism (Cambridge University Press, 2015). 